\title{
WHAT ECONOMICS OF SHORTAGE AND THE SOCIALIST SYSTEM HAVE TO SAY TO THE (HUNGARIAN) READERS TODAY
}

\section{- An Introductory Study to the First Two Volumes of the Life's Work Series}

János KORNAI

(Received: 9 April 2012)

The publisher and I chose as the first two volumes the two works that offer a comprehensive analysis of the socialist system. I would recommend that readers begin with The Socialist System, a summary of its political economy that first appeared in 1992, as it synthesizes several decades of my research, and then continue with Economics of Shortage, published in 1980, where I sought to place analysis of the socialist economy in operation on new foundations, and met with a degree of worldwide interest that I had not expected either.

\section{TWO BOOKS - TWO HISTORICAL JUNCTURES}

Hardly more than a decade passed between the publications of the two books (The Socialist System appeared in English in 1992 and Hungarian in 1993; Economics of Shortage appeared in both languages simultaneously in 1980), but that short period covered a great turn of events in modern world history: the demolition of the Berlin Wall and the collapse of the Soviet Union, initiated by the change of system in the former socialist countries.

My thinking, my outlook on the world and my system of values did not undergo any fundamental change, although I grew a good decade older and richer with some important experience, of course. I held the same view of the socialist system when the Iron Curtain still divided it from the West, as I did when the Iron

Corresponding address: J. Kornai, Corvinus University of Budapest, Fővám tér 8, H-1093 Budapest, Hungary. E-mail: janos.kornai@uni-corvinus.hu 
Curtain had come down. Yet the two books differ in many respects, because each was marked by the historical points in time when they were conceived and placed before the public. I describe in detail the conception of each in my autobiography, By Force of Thought (Kornai 2005, 2007). Here I will confine myself to the most important differences.

As I was writing Economics of Shortage, the communist party still held a monopoly of power in Hungary. It sought also a monopoly of ideology, but it was unable to impose one fully. Instead, it supported, tolerated and banned works (Rainer 2001; Révész 1997; Standeisky 1996). I weighed carefully during the writing stage what were the conditions under which it was likely to appear. I wanted the book to escape the "banned" category and join that of the "tolerated" in Hungary, in other words, I wanted it to appear legally under the auspices of a Hungarian publisher. Furthermore, I wanted it to reach readers in other socialist countries, preferably by being translated and published there. But if nothing else could be arranged, let it be found in the region's academic libraries in English.

To that end I exercised conscious self-censorship. What I wrote was true to my best conviction. I wrote the truth, but not the whole truth. Economics of Shortage did not discuss subjects still taboo under the somewhat softened dictatorship that ruled in Hungary at that time. It was still impossible to discuss openly in print how the chronic, irremediable malaise of the socialist system was tied up with the political structure: the monopoly power of the communist party and the relation between the Soviet Union and other countries of the Soviet empire.

Self-censorship is painful self-mutilation, a bitter feeling for an author. Yet I decided it was better for the work to appear in mutilated form, in a legal way accessible to a wide readership, than in a complete form as a samizdat that could reach only a tiny readership.

I achieved what I set out to do. The book, after bizarre adventures with publishers' readers described in detail in my autobiography, appeared and went through three impressions in Hungary. It was published in China six years after the Hungarian edition, in 1986, and had soon sold a hundred thousand copies. Poland was the only East European socialist country where the book was published in a regular commercial form. It was printed in Czechoslovakia but in a "limited edition" for readers chosen by the communist authorities. The English translation went the rounds in the Soviet Union as a samizdat; it did not appear in Russian until 1990, the very end of the Gorbachev period. The list of countries and publication dates reflects in a strange way the breakdown process of the socialist system.

As for what was left unsaid, those who were truly observant could read between the lines. The main messages of the book accelerated the process by which tens of thousands of citizens of the socialist countries came to their senses. They realized (and this understanding was confirmed strongly by many discussions 
I had after 1990 with earlier readers of the book) that half-hearted reforms were not going to suffice to overcome the grave problems. The system itself had to be changed.

I began preparations for The Socialist System in 1983 and started to write text in 1988. The walls of the old system still stood, but they were crumbling. By the time the book was finished, the concrete walls and barbed-wire fences that inhibited people's freedom of movement were down, and so were the constraints and taboos on the free flow of ideas. While the word "party" did not appear in Economics of Shortage, the substantive discussion in the The Socialist System began with analysis of the party's role, political power and ideology. The book stated what I had been unable to express 12 years earlier: the origin and operation of the socialist system can only be understood truly by starting from the role of political power and official ideology.

Assessing scientific works is a matter for readers, journal reviews, and later, on behalf of posterity, researchers into the history of theory. But the way an author ranks his own works is not without interest either, although it will not be free of feeling or bias. Asked which work of mine had the biggest influence, I would say without hesitation Economics of Shortage. This impression can be confirmed in several ways: citation counts, statements of contemporaries about influences on their ideas, or numbers of reviews (e.g. Hámori 2012; Felcsuti 2012). That is why my publisher, Kalligram decided to make Economics of Shortage the first volume in this series. Asked which writing of mine in the ranking of my works I think is the most important one, I would pick The Socialist System. That is my most ambitious work, an attempt to synthesize several decades of my research, in which I sought to provide an analysis that I intended should cover all the main attributes of the system.

An attempt to summarize and to provide a broad view leaves too little space for details. The title of Chapter 11 of The Socialist System is "Shortage and Inflation: The Phenomena" and of Chapter 12, "Shortage and Inflation: The Causes". Magnifying or "zooming in" on these two chapters, we find that they cover most of the subject-matter of Economics of Shortage. The latter gives much more details; it gives the chance to analyse relations important in themselves that do not, however, constitute basic attributes of the system. Of the two books, Economics of Shortage is the more colourful; it contains more ideas that were considered new and intellectually stimulating at the time it appeared. The two books complement each other and belong together, which is why the first two titles in the series share an introduction.

I have a clear conscience in presenting these two books to future researchers. Three decades have passed since the first appeared, two since the second, in which changes of historic import have occurred in Hungary, the former socialist region, 
and the whole world. Many authors would rather withdraw what they wrote earlier. I am glad we can now present the original books to readers in photographic, scanned form, without changing a single word. I stand by every word I wrote then. If a future historian wishes in future decades or centuries to look back on the $20^{\text {th }}$ century and understand the socialist system, which governed a third of humanity at its peak, these two books will be among the vast literature available as source materials.

But do these two works have something to say not only to historians specializing in socialism, but to the public today?

\section{AN ANTIDOTE TO NOSTALGIA FOR THE OLD SYSTEM}

There have been several international surveys to confirm that much of the public in all post-socialist countries look back wistfully on the former socialist system (Rose 2005). Hungary is among the countries where this nostalgia is at its highest (Vásárhelyi 2005). Table 1 reports on a survey made in 2010. Adding together the proportions in the first and second columns - those who agree wholly or partially with comparative statements about the system - yields astonishing sums: some two-thirds of the respondents are drawn more to the Kádár era (1957-1989) than to the present conditions, considering that more attention was paid then to ordinary people and that it was the fairer of the two.

Table 1

Evaluation of the Kádár system (percentages of respondents)

\begin{tabular}{lcccc}
\hline Statements & $\begin{array}{c}\text { Wholly } \\
\text { agree }\end{array}$ & $\begin{array}{c}\text { Partially } \\
\text { agree }\end{array}$ & Disagree & $\begin{array}{r}\text { Don't } \\
\text { know }\end{array}$ \\
$\begin{array}{l}\text { The Kádár system paid more attention to the } \\
\text { problems of ordinary people }\end{array}$ & 46 & 32 & 13 & 9 \\
$\begin{array}{l}\text { The change of system did more harm than } \\
\text { good to the country }\end{array}$ & 27 & 41 & 24 & 8 \\
$\begin{array}{l}\text { The Kádár system was fairer than the } \\
\text { present one }\end{array}$ & 33 & 36 & 21 & 10 \\
$\begin{array}{l}\text { The introduction of capitalism into Hungary } \\
\text { did more harm than good }\end{array}$ & 28 & 46 & 17 & 9 \\
\hline
\end{tabular}

Note: The survey covered a representative sample of 1000 persons.

Source: Communication from Mária Vásárhelyi based on the 2010 survey by the Hungarian Academy of Sciences/Eötvös Loránd University Research Group of Communications Theory. Unpublished data. 
Table 2 approaches the problem from the opposite direction by measuring the level of acceptance of the capitalist system.

Table 2

Approval of change to capitalism (percentages of respondents)

\begin{tabular}{lccc}
\hline Country & 1991 & 2009 & $\begin{array}{c}\text { Percentage points of } \\
\text { difference between the two }\end{array}$ \\
\hline Slovakia & 69 & 66 & -3 \\
East Germany & 86 & 82 & -4 \\
Russia & 54 & 50 & -4 \\
Czech Republic & 87 & 79 & -8 \\
Poland & 80 & 71 & -9 \\
Ukraine & 52 & 36 & -16 \\
Bulgaria & 73 & 53 & -20 \\
Lithuania & 76 & 50 & -26 \\
Hungary & 80 & 46 & -34 \\
\hline
\end{tabular}

Notes: The question put in the survey was: "Do you approve of the move to capitalism?" The first two columns show the proportion of respondents (who answered yes). The table was taken from Hámori - Szabó (2010: 879).

What can explain the strength of retrospective acceptance of the old system in this country? Why is the disillusionment with the new system greater than in most other post-socialist countries? My guess is that there are several factors at work; here I would like to express a few thoughts on one of these assumed influences.

The Nobel Prize-winning psychologist and economist Daniel Kahneman reported on an exciting experiment in several of his works (Kahneman et al. 1993; Redelmeier - Kahneman 1996). Colonoscopy, a diagnostic procedure for examining the large intestine, was until recently a highly painful examination that took 20-30 minutes. (The pain and discomfort have since been reduced substantially.) In the period when the examination still caused pain, researchers asked volunteers awaiting it to record continuously on the keys of a special instrument how severe they felt the pain to be. The instrument would then plot a graph of the pain intensity over time. When the examination was over, the respondents were asked to gauge how painful it had been overall. The following were found. Those who rated the examination overall less painful corresponded to those who had experienced no or only slight pain towards the end of it - even if in some cases the graph over time showed conclusively that they had suffered more than others had.

Kahneman drew far-reaching psychological conclusions from the experiment and other similar studies covering both subjective assessments of suffering and pain, and those of joys and happiness. Actual experiences (felt by the sufferers at each moment) differed strongly from memories of the experiences, but the overall 
assessments are based on the latter. "All's well that ends well", as they say. The end of a sequence of events is recalled more vividly and shapes the memory of the whole sequence more intensively than the intermediate stages do.

Let us return to the nostalgia felt for the Kádár era. ${ }^{1}$ It lasted for 35 years, of which the early ones were a time of merciless reprisals not matched in Hungarian history: hundreds of gibbets were erected, thousands served several years in prison, and tens of thousands were thrown out of their jobs. Ubiquitous intimidation bred mass servility. It was years before the repression gradually gave way to a form of bribery called "goulash communism", financed by foreign credits. Throughout there remained the curbs on freedom of speech and the press, the need for permission from the party secretary and personnel manager for foreign travel, the omnipresence of corruption. Throughout there were long waiting lists for state housing, telephone lines, and private cars, embittering many people. Nonetheless, a loosening of control became tangible towards the end of the period. Hundreds of thousands set out each weekend for Vienna's Mariahilfer Strasse to buy fashionable articles, refrigerators or freezers. Party cadres too enjoyed holidays (and capitalist goods surpluses) on the Spanish or Italian coast. Managers sniggered with employees over jokes against the communist system. Editors accepted with a wry smile articles that stretched permissibility in pointing to some of the glaring shortcomings of socialism. These improvements were accompanied by continuing security of employment. Mass, open unemployment was unknown. In fact, there was a labour shortage in many places, coupled in many others by "unemployment within the gates", much enjoyed by those fond of taking life easy at work.

This image of Hungary as "happiest barrack in the camp" remains sharpest in the collective historical memory of the Hungarian public. This is the socialism people long to have back.

Yet this was only the end of the story. This image of a disintegrating, increasingly comfy Kádár regime that had lost its claws depicts only one, quite short phase in the long history of the socialist system. The sufferings of previous phases have been recorded by researchers into the system and in works of literature and huge quantities of other documents, ${ }^{2}$ but these bitter experiences have faded in the collective historical memories of most of the Hungarian public. The disgust at the

1 In a superb lecture to a lay audience, Kahneman applied this train of thought to event sequences of several kinds (also on the Internet: Kahneman 2010). I extend the Kahneman theory at my own intellectual risk to collective memory, the process by which a large community absorbs historical experience into its soul.

2 In his splendid The Whisperers: Private Life in Stalin's Russia, Orlando Figes (2007) gives an astonishing account of how Soviet families lived and of ties between grandparents and grandchildren, parents and children, husbands and wives, brothers and sisters, and friends. The rich and varied documentation on which the book rests includes carefully kept and concealed diaries, letters between family members and friends, statements filed at the secret police, work by 
old regime is much stronger in countries like East Germany, the Czech Republic and Slovakia, where the dictatorship remained hard until the last moment.

One antidote to nostalgia for the old system is to explore its real nature. Those fully aware of the inherent attributes and chronic problems of the socialist system and how they derive from its fundamental traits become more resistant to the wiles of a distorted assessment based on short memory. The brutal or less brutal repression, the crude or less crude, more artful restriction of freedom of speech, and the very intensive and in some fields excruciating shortages: all are necessarily concomitants of the socialist system.

Of course I do not imagine that those who fully endorsed the first statement in Table 1 ("The Kádár system paid more attention to the problems of ordinary people") will suddenly change their view if they read The Socialist System, if for no other reason because it is not written in a "dramatic" style - it does not describe the traumas caused by the system or present a brightly painted picture of people's sufferings and humiliations. I aimed at an objective style that appealed to the intellect, not the feelings. Much though I would like many people to read the book, I cannot in my most confident moments imagine it being a best-seller. I do not see huge numbers of people setting about scrutinizing its 640 pages.

However, I would think it is desirable for as many as possible among those with a formative influence on public opinion to do so. Here I would mention teachers, from primary up to university level, those working in the press and the media, professional politicians, leading civil servants past and present, and practitioners of many other professions. I would like them to include many who are very critical of the old system, yet actually know little about it, and content themselves with a few slogans of dismissal and hatred. These two books are not just for professional researchers into comparative economics or political history. They provide useful information for a broad opinion-making stratum. I would like to encourage them to rethink and reshape their ideas.

\section{HOW ELEMENTS OF THE SOCIALIST SYSTEM CREEP IN}

Both books place at the centre of their analysis two "pure" theoretical models: the classical socialist system and the classical capitalist system differ diametrically; their basic attributes are wholly opposite to each other. One is a shortage economy, the other a surplus economy; one is marked by signs of excess demand, the

contemporary writers, interviews, and personal memories of elderly people still alive at the time of the political changes. Let us hope there will one day be a similar book on private life in Hungary under Rákosi and Kádár. 
other by those of excess supply. ${ }^{3}$ One displays a chronic shortage of labour, the other chronic unemployment. The main mechanism of allocation in one is bureaucratic coordination and in the other market coordination. One has public ownership as its dominant property form and the other private ownership.

Such extreme abstraction - opposing two "pure" cases - serves its purpose while the analysis remains on a purely theoretical plane. But real, historical structures are never "pure", never strictly homogenous. Some elements of one system creep into the other. Even in the most brutal period of Stalinism, the surreptitious black economy continued, despite its persecution, to obtrude the market mechanism typical of capitalism between buyer and seller. Into socialism in its slightly tamer post-Stalinist variants there crept the half-prohibited, half-permitted "grey economy", and even small private businesses appeared here and there.

This section is not concerned with these, but offers a few thoughts on "creepage" in the opposite direction. Three effects will be treated:

1. The effect after the change of system of values inherited from socialism.

2. The effect of "islands of shortage economy" that persist under the capitalist system.

3. The "soft budget constraint" syndrome under capitalism.

\section{Values inherited from socialism}

Let me recommend to the attention of readers Section 24.4 of The Socialist System, which is entitled "Preview: The Socialist System's Legacy and Post-socialism". ${ }^{4}$ At this point, I would like to pick out one idea that has gained special immediacy these days. Let me quote from the book:

great masses of people continue to adhere to moral values - attributes of a notion of a 'good society' - that their upbringing taught them to rate as socialistic values. Mean-

3 Economics of Shortage and The Socialist System deal only briefly with capitalism for the purpose of contrasting it with socialism. The line of argument is continued and augmented in my recent volume of studies Gondolatok a kapitalizmusról (Thoughts on Capitalism, 2011), where the "surplus economy" and other characteristics of capitalism are placed to the fore in the discussion. Editor's note: see Felcsuti (2012).

4 Section 24.4 does not contain a normative statement or recommend any political programme. Instead, in line with the general objectives of the book, it makes some objective predictions. The legacy of the socialist system is given; what will its effect be on the future course of events? Twenty years have passed, and the new edition of the book provides the best opportunity for checking the fulfilment of the predictions. As I see it, almost all the conjectures and expectations have proven correct. I reread those few pages with unease and dissatisfaction as a citizen, but with some reassurance and satisfaction as a researcher and author. I leave it to readers to make this comparison for themselves. 
while, they are confused; they are also drawn toward moral values that contrast starkly with these values instilled over a long period. ... To what do citizens of a postsocialist country aspire? To be left in peace by the state, undisturbed by a million regulations, and unrestricted by a hundred obligations? Or do they demand an active state that takes wise measures, cares for the unfortunate, protects the environment, and regulates the uninhibited rise in prices? Do they accept or even welcome the fact that all may earn as much as they can, or are they outraged by high incomes and demand that they be heavily taxed? ... there is also the possibility that many will relapse from time to time into the discredited ideology of bureaucratic rule, etatism, paternalism, and egalitarianism (pp. 577-580).

International comparative researches into value choices have shown that adherence to the socialist system, including the values, beliefs and moral positions of the former era, is especially strong in some post-socialist countries; Hungary is one of them. The New Europe Barometer (2009) survey had respondents in 13 post-socialist countries state whether they agreed that individuals should look after themselves and their own livelihood (full agreement $=1$ point, partial agreement $=2$ points) or whether the state should look after everyone's material welfare (partial agreement $=3$ points, total agreement $=4$ points). The average score in the 13 countries was 2.67 points, i.e. closer to paternalism than to emphasis on individual responsibility. The average obviously embraced a wide spread of scores: a sizeable proportion of the public calls strongly for state paternalism. Many other surveys show a very high proportion of people in the post-socialist region giving a high rating to the values of equality and fair income distribution. A party that plays on these expectations is likely to receive the greatest support in the political arena.

It would be useful to know better to what extent egalitarian values and demand for paternalist state care can be ascribed to the mental inheritance at the time of systemic change - persistence of the old system of values - and how much to the new system itself.

More than two decades after the first free elections, can the old expectations and value system still be influential? It is not impossible. Researchers showed recently how elements of ideology inherited from the Horthy system (1919-1945), - the conservative interpretation of the role of the nation and the family, the irredentist aspirations claiming the restoration of pre-war "greater" Hungary, etc. have persisted underground over the 45 years since the Horthy regime collapsed, and all this now undergo a resurgence. János M. Rainer (2012) uses the apt expression "underground streams" to describe the process: ideas concealed beneath the surface, passing by word of mouth from generation to generation, and breaking out when the chance presents itself. A similar course of events may be happening now with socialist ideas. Indeed, they need not be concealed, as they are stated openly by politicians on both sides of the political spectrum. Yet it may be that 
conscientious people are prompted to call for fairer distribution and fuller state care irrespective of socialistic antecedents or heritage, by the many injustices of today's society, the destitution of people abandoned without a chance of earning a living, and the lack of prospects for young people starting life at an irredeemable disadvantage. That may be one reason why many, even of those who reject one-party communist rule and all variants of the old, pre-1989 socialist system, yearn for some new, still unrealized socialist system that differs essentially from capitalism. It would be a worthwhile scientific task to study the ideological antecedents and social stimuli behind the beliefs, expectations and systems of values held by the Hungarian public today.

\section{Islands of shortage economy}

The final section of my book, The Socialist System, quoted just now, dealt not only with inherited values, but with inherited institutions as well. I rightly gauged when writing the book that this complex structure could not be changed all of a sudden, that reorganization would occur gradually, in many stages. I was also right in saying, "the old institutions may hamper the development of the new system for a long time. It takes a good while for the new institutions to evolve" (p. 578). But missing from the lines published two decades ago and now easily discerned with hindsight is the tenacity and strength of the resistance to institutional change, at least in certain spheres.

The most glaring example of this is the health sector. Here public ownership still reigns, whereas private ownership has come to dominate most areas of the economy. Indeed, the latest moves are imposing on it the ultimate form of public ownership: ownership of hospitals and clinics is now being transferred from local government bodies to the central government. Provision, at least on paper, is free of charge to those entitled to it. Feeble attempts to introduce modest contributions to the costs of services were beaten off. Now where state ownership dominates and goods or services are provided free, a shortage economy necessarily appears. This is one of the main conclusions of Economics of Shortage and it is confirmed by the broader, more comprehensive analysis of The Socialist System.

Capitalism is not a shortage economy, but a surplus economy. It is marked not by overly tight production plans that force enterprises to produce more than they are really capable of, but by chronic unutilized capacity. Retail shelves are not empty, but packed. There is no queuing for years for a phone line, but a plethora of phone companies vying for subscribers and persuading them to make maximum use of their services. 
Both books still have immediacy because they show how the state health sector works as a surviving island of socialism's shortage economy amidst the sea of the capitalist surplus economy. Look around the health sector and examples of all the phenomena of a shortage economy described in the two books can be immediately seen. The main mechanism for coordinating the provision and consumption of the services is bureaucratic rationing involving queuing and long waiting lists. Forced substitution occurs on a mass scale: patients are not seen by a chosen doctor or treated in the hospital they would wish; they are prescribed cheaper medicines than their accustomed, preferred ones. Patients, in any case in a defenceless position, are still more defenceless in a shortage economy, where the supply side is stronger than the demand side. An inevitable concomitant of a shortage economy is the appearance of corruption, whereby those on the long demand side try to bribe those on the short supply side. This takes the form in the health sector of informal payments to staff, "gratitude money" as it is called in Hungary. Insulting though the term corruption may sound, I, for one, cannot blame either those who pay it or those who receive it, as it follows inevitably from the prevailing institutional conditions.

Health care - owned by the state, subject to bureaucratic centralization, run by command-economy methods, and free of charge only in name - is far from being the only example of how distorted "islands" of the socialist system can persist or recur under capitalism. There are similar ones, for example, in education and in some segments of the welfare system. "Islands of shortage economy" also occur in capitalist countries that never underwent the historical stage of having a socialist economy. One aid to recognizing them and understanding how they work is to study thoroughly how the socialist system operated, when the shortage economy extended to all spheres of life.

\section{Soft and hard budget constraints}

I came to recognize during my studies of the socialist system that the reason why loss-making state-owned enterprises have no fear of financial collapse is that they can reckon on their higher bodies to bail them out. Their financial situation imposes no hard constraint on their expenditures as the eventuality of rescue is built into their expectations. This condition was termed a soft budget constraint (SBC) in Economics of Shortage. ${ }^{5}$ The budget constraint would be hard if a firm could

5 The term soft budget constraint and my ideas in connection with it first appeared in print in the journal Econometrica in 1979, i.e. a year before the publication of Economics of Shortage. It contained the text of the presidential address I had given at the Econometric Society Congress of 1978 , where I briefly summarized the ideas in my book, which was already in manuscript. 
not count on rescue and persistent losses led to bankruptcy, failure of the firm. If the budget constraint is soft, losses are not really a matter of life and death, and managers do not need to take prices, costs and losses to heart. Under such conditions, the incentive to reduce costs and enhance productivity economically weakens. It is possible to initiate investments irresponsibly because the higher authorities will pay the bill anyway if the costs are exceeded. Herein lays the main explanation for the low efficiency of the socialist system.

Hardness or softness of the budget constraint is not a narrow problem of accounting. It constitutes a syndrome, a complex group of social, political and economic problems with several factors concurrently at work. It has a characteristic operating mechanism and many kinds of deep and far-reaching consequences.

In the first appearance of the concept in my work, I contrasted the two "pure models", the classical socialist and classical capitalist systems, on an abstract plane. The first is marked by softness of the budget constraint and the second by hardness. But I was already pointing out that softening of the budget constraint can also be seen in many areas of present capitalist practice (Kornai 1980, 2011: 328-329).

Over 30 years have passed since the first appearance of my views on SBC, and the concept and associated theory can be said to have had a spectacular career. I will try to divide that career up into periods.

In the first period, most economists felt that SBC was a mark of state-owned enterprises under the socialist system. It applied there and only there, and they left Sovietologists and researchers specializing in the communist system to investigate it. The expression appeared often in works on the socialist system, but seldom in other contexts.

The second period began with the change of system. It suddenly became intellectually and politically fashionable for government offices and university economics departments in the former communist countries to receive visits from a succession of Western economics professors and international organization staffers, who soon realized that the budget constraint in the post-socialist countries was soft as well. It had to be hardened before the market economy would begin to work as it should. There was not a World Bank or EBRD report that did not discuss the phenomenon. By that time, the sphere of ideas covered the post-socialist transition, not just the socialist economy.

In the third period, the economists' profession began to realize that the SBC syndrome dwelt to the West of the former Iron Curtain as well. I have to admit that

However, since the sphere of ideas of the soft budget constraint arose from the work done on the book Economics of Shortage, it is justifiable to link it primarily with the 1980 book, not the 1979 article. 
to my mind the recognition spread at the speed of a snail, but a less impatient assessment would be that the concept and the theories associated with it became known quite widely. Various economic dictionaries and encyclopaedias gave the concept an entry. As I was writing these lines on 11 March 2012, I entered the words "soft budget constraint" in quotes in the English-language Google search and found 392,000 hits in 0.32 of a second.

Scrolling down the first few dozen hits, the discussion was not just about the socialist system and the post-socialist transition, but in many cases also about the soft budget constraint syndrome as found in the capitalist system. The vast quantity of examples from several countries ranged from Italian hospitals to Chinese private firms, and from the handling of Greek sovereign debt to the Japanese banking sector.

The three periods are consecutive, but as in most cases of periodization, this gives a somewhat simplified picture of the spread of the idea. In fact, there were encouraging exceptions right from the start. Some researchers appreciated quite early that SBC was not solely a socialist disease, to which the Western world was immune.

The idea of a soft budget constraint has developed considerably since its first appearance. Economics of Shortage put it in words. Later, the first mathematical models were constructed, notably in a pioneering paper by Dewatripont - Maskin (1995). Many researchers have since set about modelling mathematically one or another relation of the syndrome. A question that especially took the fancy of scientists working on a plane of abstract theory was why dynamic inconsistencies appear in the behaviour of decision-makers from whom strict and time-consistent behaviour would be predicted by standard economics. Why do they pledge not to bail out troubled organizations and then rescue them after all? In American business parlance, why do they throw good money after bad? Attempts were made to examine the problem through game theory. Other researchers used other mathematical means to study the soft budget constraint syndrome.

Economics of Shortage kept to statements based on practical observations of the phenomenon. Many later works used broad, data-based empirical examinations, and some applied rigorous econometric analysis to test the hypotheses.

On the causes of the phenomenon, Economics of Shortage confined itself to a single factor: the paternalist eye the state kept on its "children", the state-owned enterprises. Having given birth to them, the state had to ensure their survival. This link certainly exists, but only as one explanatory factory of many, of course. As mentioned earlier, I censored myself when writing the book. I hinted that the negative phenomena arise ultimately out of "certain social relations, institutional attributes" (Kornai 1980, 2011: 583). I found, to my sorrow, that few of my Western 
colleagues understood our peculiar jargon: they did not catch on that by writing "institutional attributes" emphatically at the end of the book, I was aiming at the political system. They took my book to mean that I thought that the soft budget constraint and paternalism were the main factors behind the grave problems in the socialist economy and the ultimate cause of the negative phenomena. To this day, I look back baffled and slightly saddened by this misunderstanding. Perhaps they believed that I and those of my mind saw only that the state was paternalistic without noticing how the state was bound up with the communist party and its monopoly of power, and could decide on the life or death of any state-owned enterprise as it fancied.

By the time I wrote The Socialist System, I no longer had to rely on veiled allusions. Paternalism and SBC could occupy their rightful place. Table 15.1 on page 361 of the English edition depicts the main line of causality as five blocks. The deeper reasons (the undivided power of the Marxist-Leninist party; the dominant influence of the official ideology) occupy Block 1 and the ultimate consequences appearing on the surface Block 5 (forced growth, chronic shortage economy, etc.) Far from being presented as the deepest causes, paternalism and the soft budget constraint syndrome appear in the penultimate Block 4 .

As scholars discovered ever more SBC phenomena, so the list of potential explanatory factors lengthened as well. We look on cancerous diseases in a similar way. Many types of tumours exist; many organs may be afflicted, and various cancers can occur in each, differing in their courses and speeds, the likelihood of their spread, their side-effects, and many other criteria. There may be several factors behind the origin of a cancer, from genetic susceptibility through lifestyle and environmental factors, to infection. Yet we are still justified in talking of a family of diseases because each variant has essential traits in common.

The soft budget constraint syndrome may appear in state-owned or privately owned firms, in for-profit or non-profit organizations, in the state apparatus (on a central or local level) and non-state institutions. There are cases of whole branches of the economy being rescued, and ever greater heed is paid to the "topmost" level of soft budget constraint phenomena, when entire countries are bailed out financially by other countries and/or by international organizations. ${ }^{6}$

Each occurrence of SBC involves two players: an entity to be rescued and another entity, the rescuer. The latter may be prompted to a rescue operation by various factors. If the organization in trouble (whether an enterprise, bank, hospital, local government organization, or even national government) is not bailed out,

6 For a systematic review of the fields where soft budget constraint theory is applied, see Kornai - Maskin - Roland (2003). The bibliography highlights the seminal works in each. The literature on the subject has grown considerably since, but I have no knowledge of a more recent summary study. 
there will be serious consequences: many people will lose their jobs, production will be curbed by spill-over effects, state revenues will be reduced, and so on. The economic consequences will encourage discontent and political tensions. But if the bail-outs are repeated often, other troubles ensue. Decision-makers become accustomed to rescues and come to expect them - and we are up to our necks in the soft budget constraint syndrome, with all its harmful effects of encouraging waste and reducing efficiency.

This dilemma is integral to the great international debate that broke out with the international financial crisis in the autumn of 2008. Who should rescue banks and giant corporations in financial trouble? Should a financial lifebelt be thrown to countries threatened by state default? The European approach tends towards hardening of the budget constraint, the American towards softening it - but, of course, it is not so clear, for there are counter-currents everywhere, and those espousing one therapy or the other will advance only the arguments that favour their point of view. They largely omit to compare objectively all the advantages and drawbacks of softening or hardening the budget constraint.

It is remarkable how the household budget constraint has softened worldwide. Economics of Shortage could still state that the household budget constraint under the socialist system is hard. But more and more households in the post-socialist region, including Hungary, discover that their income is no real constraint on their spending, as they can obtain desired goods easily without paying cash. Credit cards, instalment plans and secured loans have created an illusion of unlimited purchases.

The indebtedness of the household sector will swell and swell until it bursts like a bubble and it turns out that the spending is beyond the spenders' means. What happens then is that some of the indebted households cannot meet their repayments. The usual dilemma of a soft budget constraint appears. If the broke households are not rescued, some of them will be in serious difficulties: utilities will be cut off and dwellings repossessed. At that point, it is not just the political and economic consequences that have to be weighed, but the moral demands of social solidarity and compassion, as well. Certainly, these people are responsible for the troubles into which they have drifted, but the hearts of all good-natured people go out to the families who are dispossessed.

There were mass rescue campaigns in Hungary in 2011 and 2012, but were the one bailed out really those in need, or were they the ones who saw profit in buying or building dwellings for rent on a mortgage and, to put it plainly, their projects "caught cold" because the business cycle did not behave as they expected? Bailing them out marks a reappearance of SBC. The mass rescue was an encouragement for them to try again. 
I could finish with the subject of the soft budget constraint at this point. I have pointed to what can be found on the subject in my two books and to a current problem. Moreover, the Google figure might imbue me with a sense of achievement. Yet I have to admit that discontent in me is stronger than my delight at the spread of this idea. I am sure that scientific analysis of the syndrome is proceeding too slowly.

The theoretical modelling is not comprehensive enough. The models (as is usually the case) map what is easily depicted in mathematical terms: here the difference between the promise by the superior body and the observance of the commitment, i.e. the inconsistency in the decision-maker's behaviour. This is important, but it is just one side of a very complex sphere of problems. Many other phenomena of the SBC syndrome still await examination.

The empirical work is not broad or comprehensive enough. Instead of referring to guesses, it would be good to have statistical surveys as a basis for saying how widely the soft budget constraint syndrome has penetrated capitalism.

Examining the secondary effects of the SBC syndrome is partly a theoretical task, partly an empirical one. How does softening the constraint affect decision-makers' sensitivity to prices and costs? According to the usual demand functions, demand is determined mainly by price and income, but the explanatory variables should also include an indicator expressing the softness/hardness of the budget constraint. The basic axioms of standard microeconomics rest on the assumption (not explicitly stated) that the budget constraint of decision-making units is perfectly hard. The validity of all axioms needs re-examining if this is supplanted by an initial assumption that the budget constraint on some decision-making units is not perfectly hard.

Behavioural economics sets out to explain decision-makers' motivation as fully as possible. It aims, for instance, to extend beyond the simplified statement that firms "maximize profits". One factor influencing motivation at all levels (households, firms, public institutions, central governments) is certainly the degree of hardness or softness of the budget constraint. The more virulent the factor is, the more managers' attention is transferred from production and market matters towards building close relations with government and politicians, for they will give the help in times of trouble.

One especially painful shortcoming is that not a step has been taken to devise a normative theory of the SBC syndrome. I am not expecting researchers to provide a recipe for when to rescue and when not to, but theoretical work that assists in rethinking systematically the arguments for and against is needed.

Furthermore, there is an exciting question of political and intellectual history to be addressed. Clearly, the appearance of the SBC syndrome in current capitalism, in countries that never underwent a period of communist rule, is not a legacy of 
socialism. This syndrome is capitalism's own product. That being so, is it right to talk, as so many politicians, journalists and even academics do, of socialism creeping into capitalism? Hayek's famous book, The Road to Serfdom (Hayek 1944), left many people worried that any step away from the autonomy, self-determination and self-reliance of the individual, firm or small community and from the assumption of responsibility for its own actions, and any step towards extending state powers, was a step towards the socialist system. Though this expression of the case may have gone too far, it is certainly so that the more the SBC syndrome intrudes, the more capitalism, at least in this important respect, comes to resemble the socialist system.

More than three decades have passed since the first appearance of the idea of the soft budget constraint. I hope it will not take further decades before we come much closer to answering these difficult questions.

\section{THE SYSTEM PARADIGM}

The discussion so far has been of the extent to which the content of the two books has immediacy for readers today. However, there emerges another important point: to what extent can the scientific apparatus and method of the two books be used in analysing other subjects? Are the concepts and methods of examination, and the philosophy of science position behind them, workable when applied to other subjects?

The approach I have employed resembles in several respects those of two other strands: institutional economics and behavioural economics. There is much overlap, but it may not be immodest to claim that these two books and my other works added something to the methodology of the two strands mentioned.

Most works inspired by institutional or behavioural economics have a partial nature. They describe and explain the behavioural or operative attributes of some organization, legal institution or phenomenon. Both books treated here place the emphasis on examining whole systems. One of the key issues in research is how the elements of a complex social/economic/political edifice splice together, what effects they have on each other, and what the main directions and counter-effects of those are. In one study, I termed this approach the system paradigm (Kornai 2000).

Those employing the system paradigm are especially interested in phenomena that are system-specific - typical of one system or the other. They set out to clarify what features of the system bring the system-specificities into being. Capitalism has deeply rooted, genetic features that necessarily prompt entrepreneurs to innovation; this is one of its principal characteristics, advancing technical progress at 
high speed. Socialism, on the other hand, has deeply rooted, genetic traits that cause such inducements to be absent, or inescapably slow down the innovation process.

The scales do not tip in capitalism's favour in every respect. The socialist system, at a certain level of growth, reaches a state in which all reserves of labour have been absorbed and excess demand for it appears, whereas the capitalist system has an unfortunate, but genetically inescapable trait of mass, chronic unemployment that eases in times of economic upswing but never ceases altogether.

The methodology of the system paradigm is applied in the two books of the Kalligram life's work series appearing now. At most, it mentions in passing for the sake of comparison one or other of the system-specific traits of capitalism.

I have attempted in some more recent of works of mine to go further. My Thoughts on Capitalism uses the methodology of the system paradigm for a general analysis of the capitalist system. This is a direct continuation of my earlier work. The graph on page 235 of the Hungarian edition of Economics of Shortage presents the activity rates and level of economic development in 1980 (Kornai 1980, 2011). The later volume reproduces the graph and contrasts it with the relation in 2009 (Kornai 2011: 114). To take another example, the line of argument in The Socialist System is illustrated in condensed form in the diagram on page 361, showing the main directions of causality among the elements of the system. The new volume uses a diagram with a similar purpose to show those of the capitalist system. (Kornai 2011: 140). The latter diagram is a kind of mirror reflection of the one for the socialist system.

The article entitled "Centralization and the Capitalist Market Economy in Hungary" published in early 2012 differed from the volume (Kornai 2011) just mentioned in dealing not with general, lasting attributes of a system, but with the structure of power and control built up under the capitalist system by the present Hungarian regime (Kornai 2012). ${ }^{7}$ Concepts such as the alternative mechanisms of bureaucratic and market coordination, or the affinity or "foreign-ness" of elements of the system, had proven to be viable. It seemed justified to approach matters by asking whether we see around us random, single problems, or a system with defined, describable attributes in the making. Wherever the structure of the system becomes fixed, and mutually reinforcing relations develop

$7 \quad$ Volume III in my Selected Works will include my 1957 book, which appeared in English as Overcentralization in Economic Administration (Kornai 1957/1959). Included in the same volume will be my 2012 article on the present-day tendency to centralization in Hungary (Kornai 2012). The volume will provide an occasion for commenting with present-day eyes on my earlier theoretical and empirical works on the subject of centralization. I do not wish to anticipate myself here by examining the content of that important subject, merely to note the applicability of the methodology. 
among its elements, it is almost inevitable that lasting effects specific to the system will appear.

I am convinced that the system paradigm will prove workable in the hands of other researchers. There are some, not a few in fact, who use it. I trust that this new publication of Economics of Shortage and The Socialist System will help to spread this research apparatus and method more widely.

\section{REFERENCES}

Dewatripont, M. - Maskin, E. (1995): Credit and Efficiency in Centralized and Decentralized Economies. Review of Economic Studies, 62(4): 541-55.

Felcsuti, P. (2012): Book Review on Kornai's Gondolatok a kapitalizmusról. Négy tanulmány (Thoughts on Capitalism. Four Studies). Acta Oeconomica, 62(1): 113-122.

Figes, O. (2007): The Whisperers. Private Life in Stalin's Russia. London: Penguin Books.

Hámori, B. (2012): Kornai János válogatott munkái sorozat a pozsonyi Kalligram kiadásában (The Series of Selected Works of János Kornai being published by Kalligram of Bratislava). Közgazdasági Szemle, 59(2): 220-28.

Hámori, B. - Szabó, K. (2010): A gyenge hazai innovációs teljesítmény intézményi magyarázatához. Vitaírás a nemzetközi innovációs versenyben való részvétel akadályairól (Towards an Institutional Explanation for Hungary's Weak Innovation Performance. A Polemic on the Obstacles to Participation in International Innovation Competition). Közgazdasági Szemle, 57(10): 876-97.

Hayek, F. A. von (1944): The Road to Serfdom. Chicago: Chicago University Press.

Kahneman, D. - Fredrickson, B. L. - Schreiber, C. A. - Redelmeier, D. A. (1993): When More Pain is Preferred to Less: Adding a Better End. Psychological Science, 4: 401-5.

Kahneman, D. (2010): The Riddle of Experience vs. Memory. TED, March 1: http://www.ted.com/talks/lang/hu/daniel_kahneman_the_riddle_of_experience_vs_memory.html.

Kornai, J. (1957): A gazdasági vezetés túlzott központositása (Overcentralization in Economic Administration). Budapest: Közgazdasági és Jogi Könyvkiadó.

Kornai, J. (1959): Overcentralization in Economic Administration. Oxford: Oxford University Press.

Kornai, J. (1979): Resource-constrained Versus Demand-constrained Systems. Econometrica, 47(4): 801-819.

Kornai, J. (1980/2011): A hiány (Shortage). Budapest: Közgazdasági és Jogi Könyvkiadó.

Kornai, J. (1980): Economics of Shortage. Amsterdam: North-Holland.

Kornai, J. (1992): The Socialist Sytem. Oxford: Oxford University Press - Princeton: Princeton University Press.

Kornai, J. (1993): A szocialista rendszer (The Socialist System). Budapest: Heti Világgazdaság Kiadó.

Kornai, J. (2000): The System Paradigm. In: Schekle, W. - Krauth, W.-H. - Kohli, M. - Elwert, G. (eds): Paradigms of Social Change: Modernization, Development, Transformation, Evolution. Campus Verlag, Frankfurt/Main - New York, pp. 111-130.

Kornai, J. (2005): A gondolat erejével (By Force of Thought). Budapest: Osiris.

Kornai, J. (2007): By Force of Thought. Cambridge, MA: MIT Press. 
Kornai, J. (2011): Gondolatok a kapitalizmusról. Négy tanulmány (Thoughts on Capitalism. Four Studies). Budapest: Akadémiai Kiadó.

Kornai, J. (2012): Centralization and the Capitalist Market Economy in Hungary. CESifo Forum, 13(1): 47-59, www.kornai-janos.hu.

Kornai, J. - Maskin, E. - Gérard, R. (2003): Understanding the Soft Budget Constraint. Journal of Economic Literature, 41(4): 1095-136.

New Europe Barometer (2009): Centre for the Study of Public Policy, University of Aberdeen, Scotland. http://www.abdn.ac.uk./cspp/view_item_php?id=404 (uploaded 12 December 2009).

Pew Research Center (2009): The Pulse of Europe 2009: 20 Years after the Fall of the Berlin Wall. End of Communism Cheered but now with more Reservations. Washington, D.C. http://pewglobal.org/2009/11/02/end-of-communism-cheered-but-now-with-more-reservations/ Retrieved 30 March 2012.

Rainer, M. J. (2011): Bevezetés a kádárizmusba (Introduction to Kádárism). Budapest: 1956-os Intézet - L'Harmattan Könyvkiadó és Terjesztő Kft.

Rainer, M. J. (2012): Búvópatakok (Underground Streams). Élet és Irodalom, 10 February 2012.

Redelmeier, D. A. - Kahneman, D. (1996): Patients' Memories of Painful Medical Treatments: Real-time and Retrospective Evaluations of Two Minimally Invasive Procedures. Pain, 66: 3-8.

Révész, S. (1997): Aczél és korunk (Aczél and our Age). Budapest: Sík Kiadó.

Rose, R. (2005): Insiders and Outsiders. New Europe Barometer, 2004. Glasgow: Centre for the Study of Public Policy.

Standeisky, É. (1996): Az írók és a hatalom, 1956-1963 (Writers and the Power, 1956-63). Budapest: 1956-os Intézet.

Vásárhelyi, M. (2005): Csalódások kora. Rendszerváltás alulnézetben (Age of Disillusionments. Change of System Seen from below). Budapest: MTA Társadalomkutató Központ. 